

\title{
UJI OPERASIONAL ALAT TANGKAP RAMAH LINGKUNGAN JARING CIKER (JARING TIGA LAPIS ATAU TRAMMEL NET)
}

\author{
Wawan Kurniawan, Agus Riyanto dan Amani Edi Santoso \\ Teknisi Litkayasa Pada Balai Besar Penangkapan Ikan, Semarang \\ Teregistrasi I tanggal: 06 Maret 2017; Diterima setelah perbaikan tanggal: 08 Juni 2017; \\ Disetujui terbit tanggal: 13 Juni 2017
}

\section{PENDAHULUAN}

Peraturan Menteri Kelautan Perikanan (Permen KP) Nomor 02/PERMEN-KP/2015, tentang Larangan Penggunaan Alat Penangkapan Ikan Pukat Hela (Trawls) dan Pukat Tarik (Seine Nets) di Wilayah Pengelolaan Perikanan Negara Republik Indonesia. Pelarangan ini dilakukan dengan pertimbangan bahwa penggunaan alat penangkapan ikan Pukat Hela dan Pukat Tarik di Wilayah Pengelolaan Perikanan Negara Republik Indonesia telah mengakibatkan menurunnya sumber daya ikan dan mengancam kelestarian lingkungan sumber daya ikan. (PERMEN KP).

Dampak yang ditimbulkan dengan adanya larangan pengoperasian pukat hela udang menimbulkan adanya kelimpahan sumberdaya yang tidak termanfaatkan dengan maksimal serta terjadinya kelangkaan hasil tangkapan udang. Selain dampak tersebut, juga terjadi perubahan siklus hidup udang yang diamati saat ini cenderung bergerak ke pesisir atau pada jalur I dan II yang merupakan dominasi daerah penangkapan udang skala kecil. Dalam rangka memberikan alternatif dari dampak yang ditimbulkan dengan diberlakukannya peraturan tersebut di atas, maka dilakukan upaya mencari alternatif alat tangkap ramah lingkungan sebagai solusi dalam rangka pengalihan alat tangkap pukat hela udang. Sedangkan saat ini, penangkapan udang umumnya dilakukan dengan menggunakan alat tangkap yang sederhana seperti jaring insang dengan ukuran skala kecil. Upaya yang dilakukan oleh nelayan saat ini belum sebanding dengan ketersediaan sumberdaya udang yang saat ini sedang meningkat serta kebutuhan pasar terhadap udang.

Modifikasi yang dilakukan untuk meningkatkan kualitas dan kuantitas hasil tangkapan udang dengan meminimalisir dampak kerusakan yang terjadi akibat dari pengoperasian teknologitersebut.Untuk itu, dilakukan uji operasional teknologipenangkapan udang yang tidak merusak untuk pemanfaatan sumberdaya perikanan udang yang bertanggung jawab.

AdapunTujuan umum dari kegiatan ini adalah mencari alternatif alat tangkap ramah lingkungan sebagai solusi dalam rangka pengalihan alat tangkap pukat hela udang untuk pemanfaatan sumberdaya udang secara optimal.

\section{POKOK BAHASAN \\ Bahan dan Metoda}

\section{Bahan dan Alat}

Bahan dan alat yang dipergunakan dalam kegiatan ini adalah untuk mendukung kegiatan identifikasi dan uji operasional alat tangkap ramah lingkungan berupa Jaring Ciker seperti tercantum dalam Tabel 1 dan 2:

Tabel 1. Bahan yang digunakan

\begin{tabular}{lll}
\hline No & Bahan & Kegunaan \\
\hline 1. & Hasil tangkapan & Sampel pengukuran \\
2. & Kertas HVS A4/F4 dan block note & Menulis dan menggambar data \\
3. & kayu & Sebagai bahan penunjang survei \\
4. & Tali & Bahan pembuatan jarring \\
5. & Benang & Bahan pembuatan jaring \\
6. & Bahan jaring PE & Bahan pembuatan jaring \\
7. & Jaring ciker eksisting & Melakukan uji komparasi \\
8. & Batu, pasir, dan semen, timah & Bahan pembuatan pemberat \\
\hline
\end{tabular}

Korespondensi penulis:

Jl. Yos Sudarso, Kalibaru Barat, Tanjung Emas, Bandarharjo, Semarang Utara,

Kota Semarang, Jawa Tengah 50175, Indonesia 
Tabel 2. Peralatan yang digunakan

\begin{tabular}{|c|c|c|}
\hline No & Peralatan & Kegunaan \\
\hline 1. & Kuesioner & Form isian saat melakukan wawancara \\
\hline 2. & Alat perekam & $\begin{array}{l}\text { Back up data hasil wawancara yang tidak tercatat } \\
\text { pada kuesioner }\end{array}$ \\
\hline 3. & $\begin{array}{l}\text { Alat tulis: } \\
\text { papan jalan, pensil, pulpen, } \\
\text { penghapus, rautan }\end{array}$ & Untuk mencatat data hasil pengukuran \\
\hline 4. & Camera digital & $\begin{array}{l}\text { Mendokumentasikan keadaan/lokasi, deskripsi } \\
\text { sarana tangkap, dan hasil tangkapan }\end{array}$ \\
\hline 5. & Perangkat komputer & $\begin{array}{l}\text { Memasukan dan menganalisa data, Membuat dan } \\
\text { Mempresentasikan laporan uji coba }\end{array}$ \\
\hline 6. & Frame pengukuran & Dimensi dalam mengukur panjang ikan \\
\hline 7. & Global Position System (GPS) & Tracking dan pengambilan posisi \\
\hline 8. & Buku identifikasi udang & Panduan dalam menentukan jenis udang \\
\hline 9. & Peta laut & $\begin{array}{l}\text { Panduan dalam menentukan daerah penangkapan } \\
\text { udang }\end{array}$ \\
\hline 10. & Alat gambar & $\begin{array}{l}\text { Untuk menggambar sarana dan daerah } \\
\text { penangkapan udang }\end{array}$ \\
\hline 11. & Kapal dan mesin penggerak & Sarana melakukan uji operasional \\
\hline 12. & Coban & Menjurai jaring \\
\hline 13. & Meteran & Mengukur ikan dan sarana penangkapan ikan \\
\hline
\end{tabular}

\section{Sarana Apung}

Sarana apung yang digunakan terdiri dari perahu motor penangkapan udang yang berupa perahu loang boat, perahu ini menggunakan mesin yang umum digunakan oleh nelayan setempat. Spesifikasi kapal angkut tersebut terdiri dari (Gambar 1):

1. Jenis kapal : Longboat

2. Ukuran kapal : $P \times L \times D: 10,0 \times 1,00 \times 0,80 \mathrm{~m}$

3. Motor penggerak: Mesin Yamaha, $15 \mathrm{PK}$



Gambar 1. Perahu motor penangkapan udang.

\section{Metoda}

Tahapan kegiatan uji operasional alat tangkap dilakukan dalam tiga tahap yaitu tahap identifikasi, pembuatan alat, dan uji operasional alat. Tahapantahapan tersebut dapat dirinci sebagai berikut:

1) Identifikasi

Uji operasional memerlukan suatu prototype yang merupakan modifikasi dari teknologi eksisting (alat tangkap jaring yang sudah dimiliki nelayan untuk menangkap udang). Prototype dapat dioperasikan secara maksimal untuk optimalisasi penangkapan udang. Untuk merancang prototype tersebut dibutuhkan suatu identifkasi yang memadai sehingga rancangan tersebut dapat berfungsi sebagaimana teknik pengoperasian yang dikehendaki diantara nya identifikasi sarana penangkapan udang, daerah penangkapan udang, pengukuran alat tangkap serta factor-faktor lain sebagai penunjang keberhasilan suatu uji operasional.

\section{2) Pembuatan Alat}

Pembuatan alat penangkapan ikan merupakan proses setelah kegiatan survey awal selesai. Perancangan jaring ciker yang pembuatannya mengacu pada kondisi sumberdaya udang, ukuran udang, dan kondisi perahu yang digunakan untuk proses uji coba alat tangkap. Selanjutnya proses pembuatan alat dilakukan.

\section{3) Uji Operasional}

Uji operasional jaring dilakukan menurut uji komparatif antara jaring ciker hasil kerekayasaan yang 
berbahan PA dengan jaring penangkapan udang existing milik nelayan, dengan bahan dan ukuran benang serta mesh size yang berbeda yaitu untuk membandingkan lama penurunan, penarikan, ketahanan di dalam air terhadap arus, serta jenis dan ukuran ikan yang tertangkap.

\section{Hasil dan Bahasan}

\section{a. Jaring Ciker eksisting}

Jaring ciker milik nelayan Cilacap berbentuk persegi panjang yang terdiri dari tiga lapis, mata jaring Tabel 3. Spesifikasi jaring ciker eksisting di Cilacap bagian luar (outter net) $51 / 5$ inch $(139,7 \mathrm{~mm})$ dan jaring dalam (inner net) $13 / 4$ inch $(44,45 \mathrm{~mm})$. Komponen jaring ciker eksisting di Cilacap terdiri dari webbing Polyamide (PA) monofilament, tali pelampung dan pelampung, tali ris atas, pemberat, tali selambar.

Komponen dan material jaring ciker eksisting selengkapnya (dalam 1 tinting/pis) terlihat padaTabel 3 dari hasil identifikasi pengukuran alat tangkap dilapangan, sedangkan desain jaring ciker eksisting tertera pada Gambar 2.

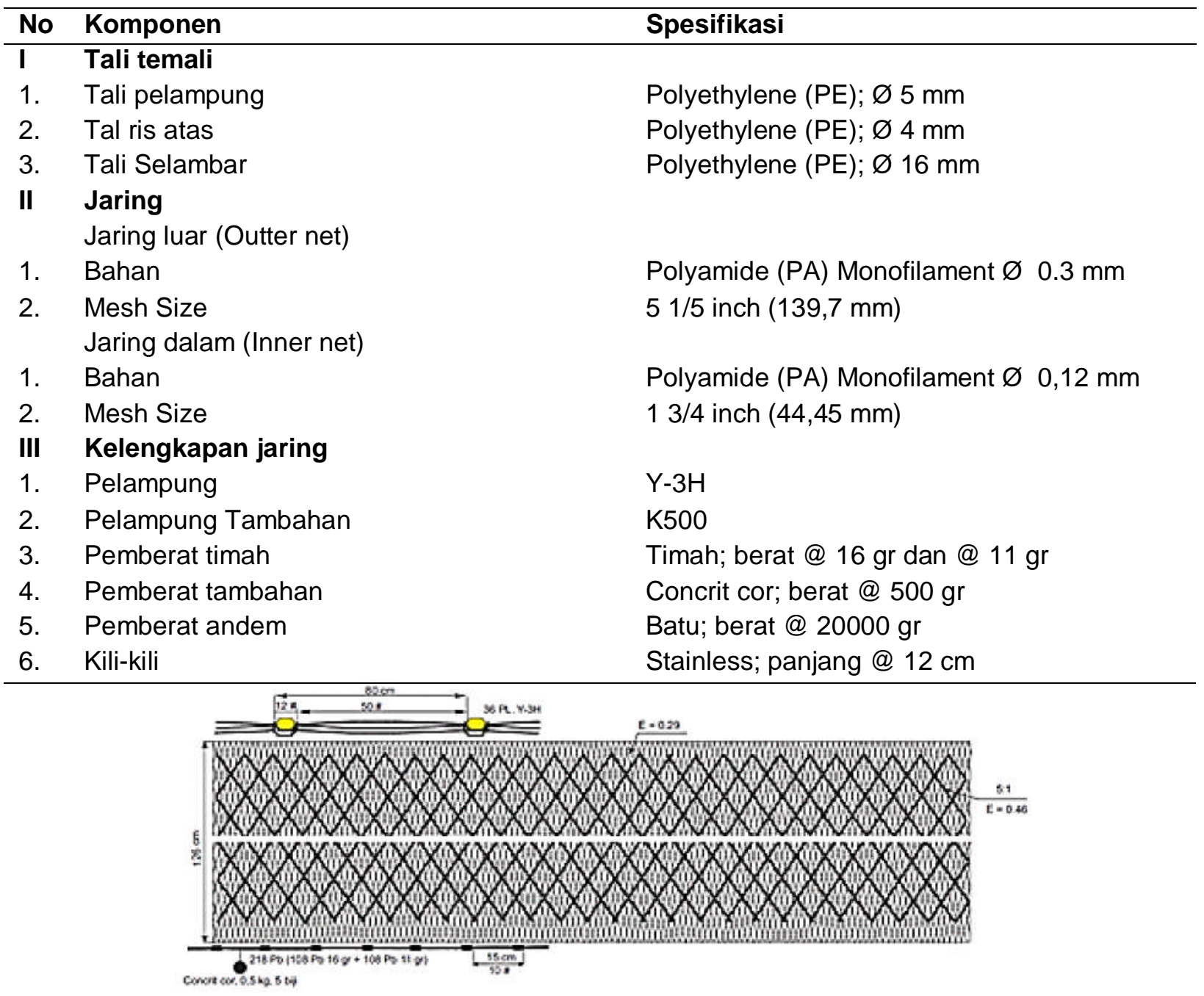

Gambar 2. Desain Jaring Ciker Cilacap.

Berdasarkan desain seperti terlihat padaGambar 1 menunjukkan nilai Hanging Ratio $(E)$ jaring bagian luar adalah 0,46 dan hanging ratio (E) bagian dalam adalah 0,29 . Konstruksi gillnet yang mendekati $E=$ 0,5 membuat udang/ikan yang tertangkap dominan dalam kondisi terjerat ( $g$ illed) sehingga ukuran ikan yang tertangkap lebih selektif. Sedangkan konstruksi gillnet yang mendekati $\mathrm{E}=0,3$ membuat udang atau ikan tertangkap secara terbelit. Hal dirancang demikian karena fungsi jaring bagian dalam (inner net) adalah untuk ikan terbelit. 


\section{b. Jaring Ciker Modifikasi}

Alat tangkap jaring ciker eksisting dianggap belum optimal dalam pengoperasiannya terutama dalam rangka optimalisasi hasil tangkapan.Modifikasi dilakukan pada komponen tali-temali, bahan dan tinggi jaring, maupun komposisi pemberat dan pelampung.Jaring ciker modifikasi juga merupakan lembaran jaring berbentuk persegi panjang yang terdiri dari jaring tiga lapis dengan ukuran mata jaring sama.Dalam pengembangan teknologi ini telah didesain 3 (tiga) prototype jaring ciker.Perbedaan dari ketiga prototype ini terletak pada bahan jaring yang digunakan.Penggunaan bahan jaring yang berbeda akan berpengaruh terhadap gaya apung dan gaya tenggelam satu unit jaring.Dengan demikian desain komposisi pelampung dan pemberat juga dilakukan terhadap ketiga prototype tersebut. Mata jaring pada ketiga prototype tersebut adalah sama, yaitu jaring luar (outter net) 6 inch $(152,4 \mathrm{~mm})$ dan jaring dalam (inner net) $13 / 4$ inch $(44,45 \mathrm{~mm})$.

Komponen jaring ciker hasil inovasi ini terdiri dari kombinasi bahan jaring yang berbeda pada masingmasing prototype. Prototype 1 terdiri daribahan webbing Polyamide (PA) monofilament pada inner netdan outter net.Prototype 2 terdiri dari bahan webbing Polyamide (PA) monofilament pada inner net dan Polyamide (PA) multifilament pada outter net. Sedangkan prototype 3 terdiri dari bahan webbing Polyamide (PA) multifilament pada inner net dan outter net.Komponen yang lain adalah tali pelampung dan pelampung, tali ris atas, pemberat, tali selambar, dan pemberat tambahan.

Komponen dan material jaring ciker inovasi BBPI dari hasil perekayasaan (dalam 1 tinting/pis), seperti terlihat pada Tabel 4.

Tabel 4. Spesifikasi jaring ciker hasil inovasi BBPI (Prototype 1) (Gambar 3)

\begin{tabular}{|c|c|c|}
\hline No & Komponen & Spesifikasi \\
\hline I & Tali temali & \\
\hline 1. & Tali pelampung & Polyethylene (PE); Ø $7 \mathrm{~mm}$ \\
\hline 2. & Tal ris atas & Polyethylene (PE); Ø $7 \mathrm{~mm}$ \\
\hline 3. & Tal penggantungan jaring & Polyethylene (PE); Ø 4 mm \\
\hline 4. & Tali Selambar & Polyethylene (PE); Ø 16 mm \\
\hline II & $\begin{array}{l}\text { Jaring } \\
\text { Jaring luar (Outter net) }\end{array}$ & \\
\hline 1. & Bahan & Polyamide (PA) Monofilament $\varnothing 0.4$ mm \\
\hline 2. & $\begin{array}{l}\text { Mesh Size } \\
\text { Jaring dalam (Inner net) }\end{array}$ & 6 inch $(152,7 \mathrm{~mm})$ \\
\hline 1. & Bahan & Polyamide (PA) Monofilament $\varnothing 0,12 \mathrm{~mm}$ \\
\hline 2. & Mesh Size & $13 / 4$ inch $(44,45$ mm) \\
\hline III & Kelengkapan jaring & \\
\hline 1. & Pelampung & $\mathrm{Y}-3 \mathrm{H}$ \\
\hline 2. & Pelampung Tambahan & K500 \\
\hline 3. & Pemberat timah & Timah; berat @ 10 gr \\
\hline 4. & Pemberat tambahan & Concrit cor; berat @ 500 gr \\
\hline 5. & Pemberat andem & Batu; berat @ 20000 gr \\
\hline 6. & Kili-kili & Stainless, $\varnothing 12 \mathrm{~mm}$ \\
\hline
\end{tabular}


Tabel 5. Spesifikasi jaring ciker hasil inovasi BBPI (Prototype 2) (Gambar 3)

\begin{tabular}{|c|c|c|}
\hline No & Komponen & Spesifikasi \\
\hline I & Tali temali & \\
\hline 1. & Tali pelampung & Polyethylene (PE); Ø $7 \mathrm{~mm}$ \\
\hline 2. & Tal ris atas & Polyethylene (PE); $\varnothing 7 \mathrm{~mm}$ \\
\hline 3. & Tal penggantungan jaring & Polyethylene (PE); Ø 4 mm \\
\hline 4. & Tali Selambar & Polyethylene (PE); Ø $16 \mathrm{~mm}$ \\
\hline II & $\begin{array}{l}\text { Jaring } \\
\text { Jaring luar (Outter net) }\end{array}$ & \\
\hline 1. & Bahan & Polyamide (PA) Multifilament, $210 \mathrm{~d} / 6$ \\
\hline 2. & $\begin{array}{l}\text { Mesh Size } \\
\text { Jaring dalam (Inner net) }\end{array}$ & 6 inch $(152,7 \mathrm{~mm})$ \\
\hline 1. & Bahan & Polyamide (PA) Monofilament $\varnothing \quad 0,12 \mathrm{~mm}$ \\
\hline 2. & Mesh Size & $13 / 4$ inch $(44,45 \mathrm{~mm})$ \\
\hline III & Kelengkapan jaring & \\
\hline 1. & Pelampung & $\mathrm{Y}-3 \mathrm{H}$ \\
\hline 2. & Pelampung Tambahan & K500 \\
\hline 3. & Pemberat timah & Timah; berat @10 gr \\
\hline 4. & Pemberat tambahan & Concrit cor; berat @ 500 gr \\
\hline 5. & Pemberat andem & Batu; berat @ 20000 gr \\
\hline 6. & Kili-kili & Stainless, $\varnothing 12 \mathrm{~mm}$ \\
\hline
\end{tabular}

Tabel 6. Spesifikasi jaring ciker hasil inovasi BBPI (Prototype 3) (Gambar 3)

\begin{tabular}{|c|c|c|}
\hline No & Komponen & Spesifikasi \\
\hline I & Tali temali & \\
\hline 1. & Tali pelampung & Polyethylene (PE); Ø $7 \mathrm{~mm}$ \\
\hline 2. & Tal ris atas & Polyethylene (PE); Ø $7 \mathrm{~mm}$ \\
\hline 3. & Tal penggantungan jaring & Polyethylene (PE); Ø 4 mm \\
\hline 4. & Tali Selambar & Polyethylene (PE); Ø 16 mm \\
\hline II & $\begin{array}{l}\text { Jaring } \\
\text { Jaring luar (Outter net) }\end{array}$ & \\
\hline 1. & Bahan & Polyamide (PA) Multifilament, $d / 6$ \\
\hline 2. & $\begin{array}{l}\text { Mesh Size } \\
\text { Jaring dalam (Inner net) }\end{array}$ & 6 inch $(152,7 \mathrm{~mm})$ \\
\hline 1. & Bahan & Polyamide (PA) Multifilament, $210 \mathrm{~d} / 2$ \\
\hline 2. & Mesh Size & $13 / 4$ inch $(44,45 \mathrm{~mm})$ \\
\hline III & Kelengkapan jaring & \\
\hline 1. & Pelampung & $\mathrm{Y}-3 \mathrm{H}$ \\
\hline 2. & Pelampung Tambahan & K500 \\
\hline 3. & Pemberat timah & Timah; berat @ 10 gr \\
\hline 4. & Pemberat tambahan & Concrit cor; berat @ 500 gr \\
\hline 5. & Pemberat andem & Batu; berat@ @ 20000 gr \\
\hline 6. & Kili-kili & Stainless, $\varnothing 12 \mathrm{~mm}$ \\
\hline
\end{tabular}




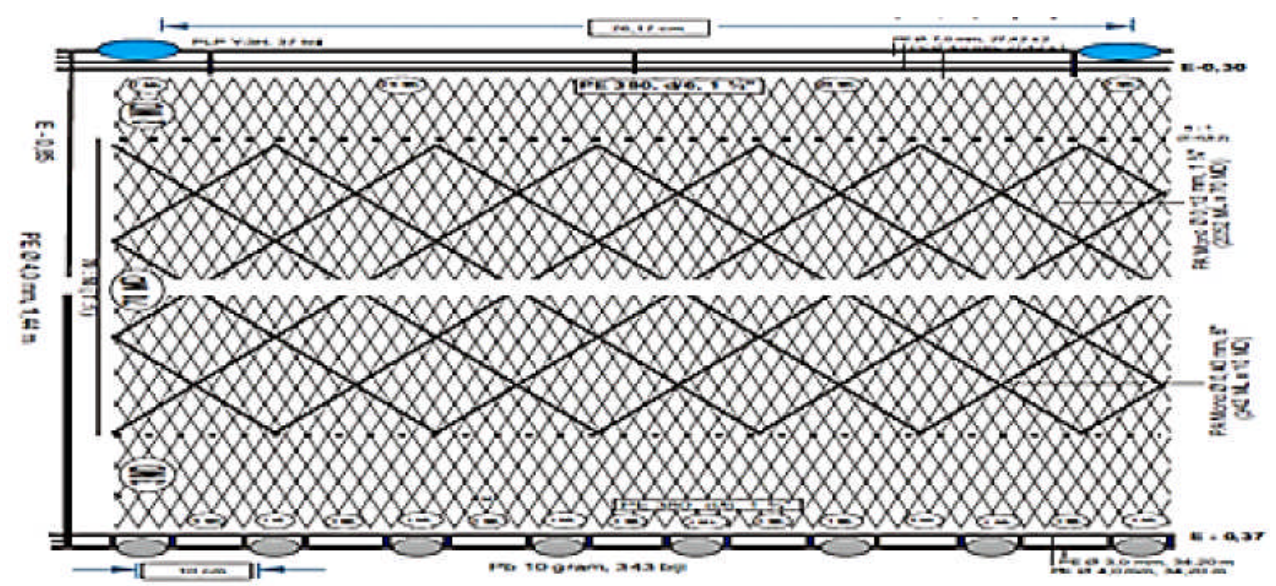

Gambar 3. Jaring Ciker Hasil Inovasi BBPI (Prototype 1).

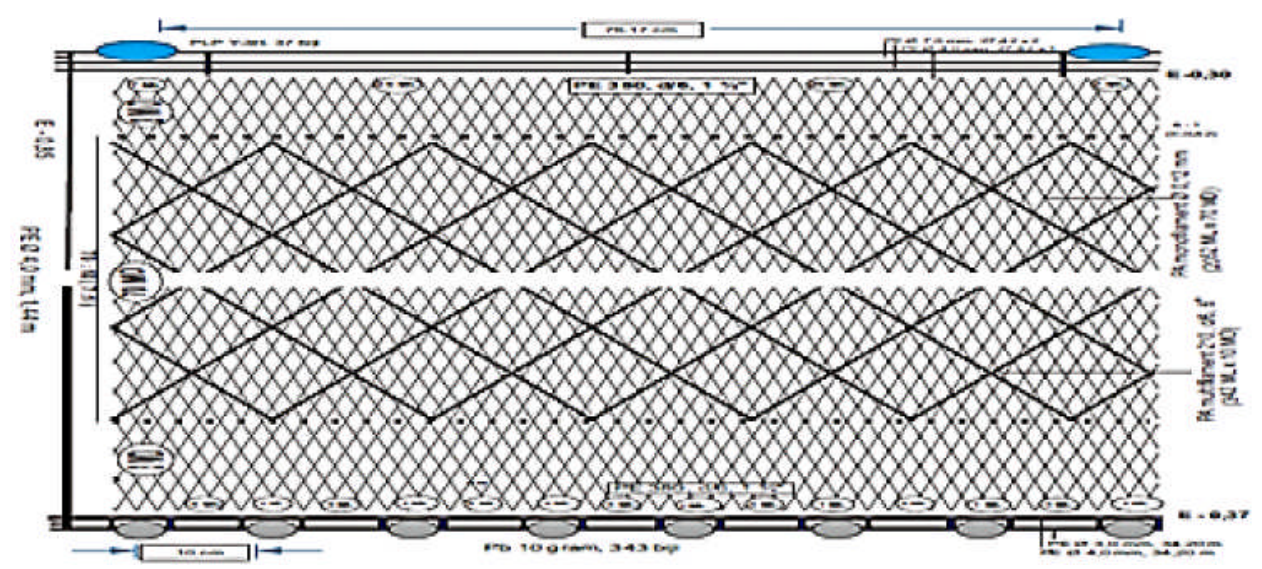

Gambar 4. Jaring Ciker Hasil Inovasi BBPI (Prototype 2).

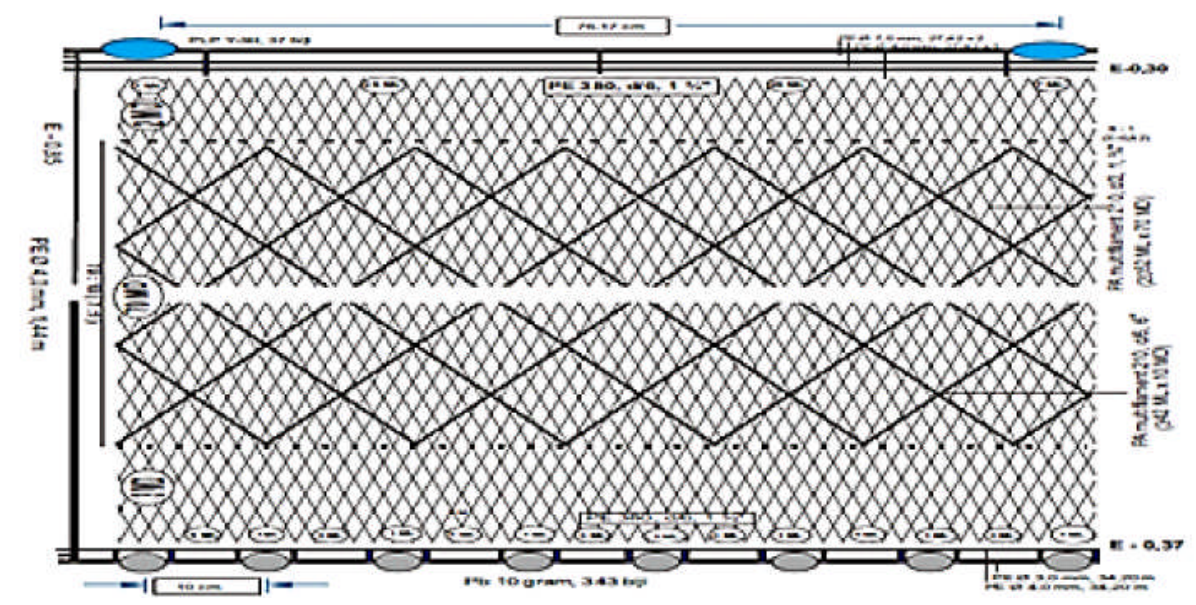

Gambar 5. Jaring Ciker Hasil Inovasi BBPI (Prototype 3).

Berdasarkan desain (Gambar 3, 4, dan 5) terlihat nilai Hanging Ratio (E) yang merupakan perbandingan antara jaring terpasang dengan panjang jaring teregang yaitu pada bagian luar adalah 0,52 dan bagian dalam adalah 0,30 . Konstruksi gillnet yang mendekati $E=$ 0,5 menyebabkan udang/ikan yang tertangkap sebagian besardalam kondisi terjerat (gilled) sehingga ukuran ikan yang tertangkap lebih selektif. Sedangkan konstruksi gillnet dengan $\mathrm{E}$ mendekati $\mathrm{E}=0,3$ membuat udang atau ikan tertangkap secara terbelit.Rancangan demikian karena fungsi jaring bagian dalam (inner net) adalah untuk ikan terbelit.

Jaring ciker hasil inovasi BBPI dirancang sama dengan jaring tiga lapis pada umumnya yaitu untuk menangkap udang secara terpuntal dan terjerat. Umumnya ikan tertangkap pada jaring bagian dalam (inner net) karena pada bagian jaring terdiri dari benang 
jaring yang cukup kecil diameternya yaitu $0.12 \mathrm{~mm}$ dan/atau $210 \mathrm{~d} / 2$ serta memiliki ukuran mata cukup kecil yaitu $13 / 4$ inch.

\section{c. Karakteristik Jaring Ciker Modifikasi}

Perancangan badan jaring ciker dilakukan dengan mempertimbangkan faktor kondisi perairan dan perhitungan, antara lain:

1) Ukuran ikan target tangkapan

Penentuan ukuran mata jaring bagian kantong didasarkan pada ukuran udang target tangkapan. Sehingga dengan asumsi ikan yang akan ditangkap berukuran panjang total kurang lebih $13 \mathrm{~cm}$, maka bukaan mata jaring pada jaring ciker untuk menangkap udang harus sesuai dengan ukuran tersebut.

Untuk kebutuhan mata jaring bagian luar (outter net) berukuran 6 inch sedangkan pada jaring bagian dalam (inner net) berukuran $13 / 4$ inch (berdasarkan jaring dipasaran).

2) Hanging ratio $(E)$

Nilai hanging ratio untuk memprediksi keregangan badan jaring saat operasi penangkapan udang, sehingga jaring dirancang agar udang dapat tertangkap secara terjerat pada jaring bagian luar dan tersangkut pada jaring bagian dalam.

Berdasarkan hasil perhitungan ditentukan bahwa untuk mengoptimalkan fungsi badan jaring dan menghindari adanya ikan terjerat dan terpuntal, maka nilai hanging ratio $(\mathrm{E})$ pada jaring bagian luar sebesar 0,5 dan pada jaring bagian dalam sebesar 0,3 .

3) Luas jaring

Kantong jaring membentuksatu bidang yaitu bidang jaring vertical. Berdasarkan kebutuhan ukuran mata jaring pada jaring ciker, maka terdapat bagian kantong jaring yang memiliki bidang dengan luasan tertentu. Bagian tersebut adalah bagian dinding jaring, dimana pada saat operasi penangkapan udang bagian dinding dalam kondisi terbentang tegak.

4) Tinggi jaring

Berdasarkan data rancangan jaring ciker, maka tinggi bidang jaring terpasang sebesar 1.4 meter. Jaring yang dirancang dioperasikan di dasar perairan.

\section{d. Pengoperasian Jaring Ciker}

Jaring ciker eksisting merupakan modifikasi dari jaring tiga lapis (trammel net). Modifikasi yang dilakukan terletak pada konstruksi jaring yang di desain untuk dioperasikan secara aktif. Metode pengoperasian dilakukan secara aktif, sedangkan jaring trammel net dioperasikan secara pasif. Pengoperasian jaring ciker dilakukan dengan cara jaring diputar hingga 450 derajat. Udang sasaran tertangkap pada jaring insang dengan cara terjerat pada bagian insang atau dengan cara terpuntal pada bagian badan. Pola penangkapan umumnya one day trip, dengan penurunan jaring hingga delapan kali. Pada umumnya nelayan berangkat pagi hari dan kembali ke fishing base pada sore hari. Dalam 1 (satu) kapal terdiri dari 2 unit jaring,masing-masing unit terdiri dari 9 tinting/pis jaring. Metode pengoperasian dapat diuraikan sebagai berikut:

\section{Pemasangan (setting);}

Proses pemasangan jaring diawali dari penurunan pelampung tanda, penurunan tali pelampung tanda, penurunan jaring, dilanjutkan dengan penurunan tali selambar. ujung tali selambar diikat pada kapal.

\section{Pemutaran (routed)}

Jaring yang sudah dipasang dilaut kemudian diputar hingga 450 derajat dengan radius sejauh panjang bentangan jaring.

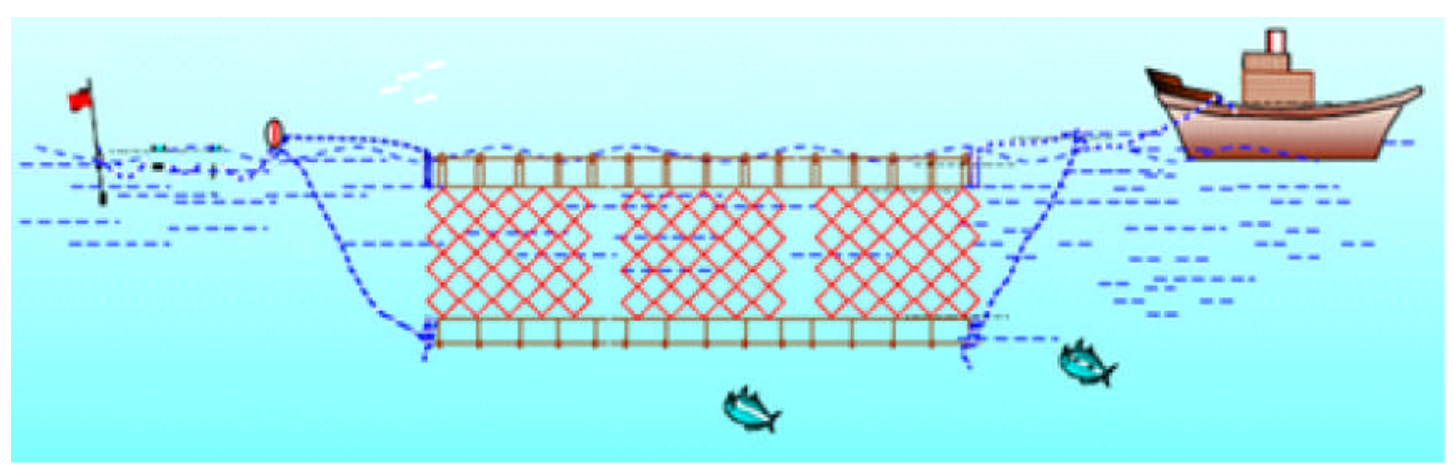

Gambar 6. llustrasi proses pemasangan jaring dalam perairan sebelum diputar. 


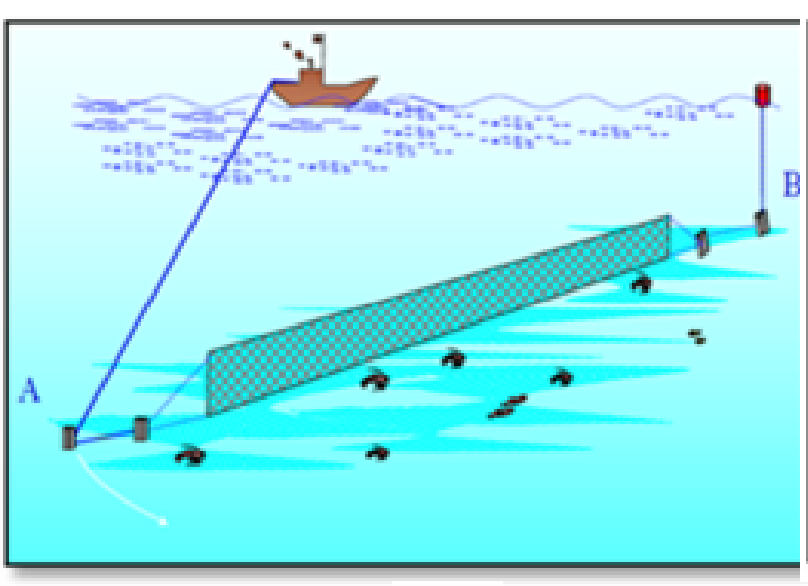

(a)

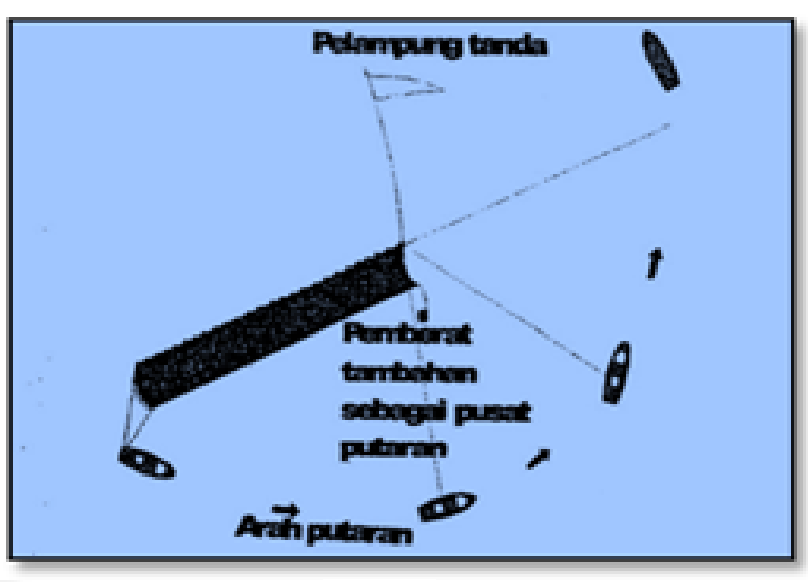

(b)

Gambar 7. llustrasi proses pemutaran (routed) jaring dalam perairan (a). dilihat dari arah horisontal, dan (b). dilihat dari arah vertical (dari atas).

Penarikan (hauling);

Penarikan jaring dimulai dengan menarik tali selambar yang terhubung ke kapal, pengangkatan 3 (tiga) buah pemberat tambahan, selanjutnya penarikan jaring dan diakhiri dengan pengangkatan pelampung tanda.

Selama proses penarikan jaring, kapal dalam kondisi bergerak perlahan dengan mesin kapal dihidupkan untuk menjaga posisi kapal terhadap arah penarikan jaring serta mempermudah dalam proses pengangkatan jaring.

\section{e. Hasil tangkapan}

Jaring ciker hasil inovasi 3 kali lebih banyak hasil tangkapannya dibandingkan dengan alat tangkap eksisting. Jika dinilai dalam rupiah dengan harga per kilogram saat pengujian adalah Rp. 160.000 maka, jaring ciker hasil inovasi memperoleh hasil penjualan sebanyak Rp. 480.000 lebih banyak daripada alat tangkap eksisting yang hanya Rp. 160.000 .

Hasil tangkapan udang dan non udang selama 4 kali uji operasional diperoleh komposisi hasil tangkapan udang dan non udang yang berbeda di setiap pengujian. Pada pengujian pertama dihasilkan komposisi udang sebanyak $47 \%$,non udang sebanyak $53 \%$. PadapengUjian kedua dihasilkan udang sebanyak $59 \%$ non udang sebanyak $41 \%$. Uji ketiga dihasilkan komposisi udang sebanyak $52 \%$ non udang sebanyak $48 \%$. Terakhir, uji keempat dihasilkan komposisi udang sebanyak $55 \%$ lebih banyak daripada non udang sebanyak $45 \%$. Jika dirata-rata empat kali pengujian diperoleh komposisi udang $53,25 \%$ lebih banyak daripada non udang $46,75 \%$, meskipun selisih nya kecil. Kecilnya selisih antara udang dan non udang dapat terjadi karena pengujian dilakukan pada saat musim paceklik udang sehingga ikan lebih dominan dari udang di dasar perairan.

\section{KESIMPULAN}

Kegiatan Uji operasional alat tangkap ramah lingkungan telah dilaksanakan dan diperoleh beberapa kesimpulan sebagai berikut:

1. Alat tangkap ramah lingkungan untuk menangkap udang adalah jaring insang trammel net. Namun alat tangkap tersebut belum dapat memberikan hasil tangkapan udang yang optimal sehingga dilakukan pengembangan menjadi jaring ciker yang bersifat aktif tanpa merusak sumberdaya udang dan lingkungannya.

2. Rancangan jaring cikerhasilmodifikasi berdasarkan penggunaan bahan jaring terdiri dari3 (tiga) prototype yang bersifat aktif dengan cara diputar, dibuat dengan bahan yang berbeda bisa direkomendasikan sebagai alat tangkap yang ramah lingkungan sehingga penangkapan bisa di optimalkan.

3. Terkait dengan pengujian hasil rancangan jaring ciker diperoleh beberapa hal, yaitu perbandingan hasil tangkapan antara jaring ciker hasil inovasi BBPI dengan alat tangkap jaring ciker eksisting maupun trammel net yang dioperasikan untuk menangkap udang adalah 3 berbanding 1.Jaring ciker hasil inovasi 3 kali lebih banyak hasil tangkapannya dibandingkan dengan alat tangkap eksisting. Jika dinilai dalam rupiah dengan harga per kilogram saat pengujian adalah Rp. 160.000 maka, jaring ciker hasil inovasi memperoleh hasil penjualan sebanyak Rp. 480.000 lebih banyak daripada alat tangkap eksisting yang hanya Rp. 160.000 . 
4. Komposisi hasil tangkapan antara udang dan non udang hasil pengujian diperoleh udang $53,25 \%$ lebih banyak daripada non udang $46,75 \%$.

\section{PERSANTUNAN}

Tulisan ini merupakan bagian dari kegiatan mencari alternatif alat tangkap ramah lingkungan sebagai solusi dalam rangka pengalihan alat tangkap pukat hela udang untuk pemanfaatan sumberdaya udang secara optimal.

\section{DAFTAR PUSTAKA}

Jayanto, b.b. (2013). Analisis Keragaan Usaha Garuk Udang Dan Garuk Udang Modifikasi Di Perairan Kota Semarang. Semarang. Buletin Oseanografi Marina. 2 (104-115).

Keputusan Menteri Kelautan dan Perikanan NOMOR KEP.06/MEN/2010 Tentang Alat Penangkapan Ikan Di Wilayah Pengelolaan Perikanan Negara Republik Indonesia
Kesteven, G.L. (1973). Manual of Fisheries Science. Part 1. An Introduction of Fisheries Science. Rome (ITA): FAO Fisheries Technical Paper. No. 118, 43 hal.

Pangesti T.P. (2011). Model pengelolaan sumberdaya udang Penaeidae spp. di Kabupaten Cilacap Provinsi Jawa Tengah [Tesis]. Bogor (ID): Institut Pertanian Bogor.

Smith IR. (1983). A Research Framework for Traditional Fisheries. Manila (PIL):International Centre for Living Aquatic Resources Management(ICLARM).

Sobari MP, Kinseng RA, Priyatna FN. (2003).. Membangun Model PengelolaanSumberdaya Perikanan Berkelanjutan Berdasarkan Karakteristik Sosial Ekonomi Masyarakat Nelayan: Tinjauan Sosiologi Antropologi. Buletin Ekonomi Perikanan. 5(1):41-48. 